\title{
The Metabolism of ${ }^{14} \mathrm{G}$-Glycine and ${ }^{14} \mathrm{C}$-Bicarbonate by Washed Suspensions of the Rumen Ciliate Entodinium caudatum
}

\author{
BY G. S. COLEMAN \\ Biochemistry Department, Agricultural Research Council Institute of \\ Animal Physiology, Babraham, Cambridge
}

(Received 9 October 1963)

\begin{abstract}
SUMMARY
Washed suspensions of Entodinium caudatum incubated anaerobically in the presence of penicillin and neomycin incorporated ${ }^{14} \mathrm{C}$-glycine in the cell 'pool' as $\mathrm{N}$-acetylglycine and into the cell protein as glycine without conversion to any other amino acid. At low external concentrations the glycine was present in the protozoa themselves and was not free in the gastric sac or present solely in the intracellular or extracellular bacteria. The incorporation reached a constant value after incubation for $24 \mathrm{hr}$; after this time the uptake of glycine was balanced by an equal loss of $\mathrm{N}$-acetylglycine from the organisms. These suspensions also incorporated ${ }^{14} \mathrm{C}$ from $\mathrm{NaH}^{14} \mathrm{CO}_{3}$ into carbon atoms 3 and 4 of protozoal glucose which was probably present as starch in the intact protozoa.
\end{abstract}

\section{INTRODUCTION}

Although Entodinium caudatum can be grown in vitro in the presence of bacteria on a substrate of rice starch grains, dried grass, autoclaved rumen fluid and chloramphenicol (Coleman, 1960 a), it has not so far proved possible to grow these protozoa in the absence of bacteria (Coleman, 1962) and very little is known about the biosynthetic capabilities of this or any other Entodiniomorphid protozoon. Abou Akkada \& Howard (1962) found that although chloramphenicol-treated $E$. caudatum taken directly from the rumen rapidly hydrolysed casein, there was little simultaneous increase in cell nitrogen. However, DL-alanine, DL-leucine and DL-valine were incorporated by Ophryoscolex caudatus (Williams, Davis, Doetsch \& Gutierrez, 1961) and Epidinium ecaudatum (Gutierrez \& Davis, 1962) although with neither organism was the cellular distribution of the incorporated amino acid investigated. The present investigation was undertaken in an attempt to determine if uniformly labelled ${ }^{14} \mathrm{C}$-glycine, ${ }^{14} \mathrm{C}$-glucose, ${ }^{14} \mathrm{C}$-maltose, ${ }^{14} \mathrm{C}$-starch and ${ }^{14} \mathrm{C}$-bicarbonate were incorporated by washed $E$. caudatum grown under controlled conditions in vitro and whether any such uptake was into the intracellular bacteria or protozoal material.

\section{METHODS}

Source of protozoa. The protozoa were grown and 'inoculum cultures' prepared and treated as described by Coleman (1962) except that 'inoculum cultures' were treated each day with $15 \mathrm{mg}$. rice starch and about $10 \mathrm{mg}$. dried grass. Where the 
metabolism of ${ }^{14} \mathrm{C}$-starch or ${ }^{14} \mathrm{C}$-glucose was studied the amount of rice starch was reduced to $5 \mathrm{mg}$. on the day before the experiment.

Preparation of protozoa for inoculation. The protozoa were taken from the 'inoculum cultures' after removal of the surface scum and most of the supernatant liquid, and allowed to stand in 9 in. $\times 1$ in. tubes until any grass present had sunk to the bottom. The supernatant fluid containing the protozoa was transferred to centrifuge tubes, the residual grass washed with salt solution B (Coleman, $1960 b$ ) and the washings added to the supernatant fluid. The protozoa were spun down and

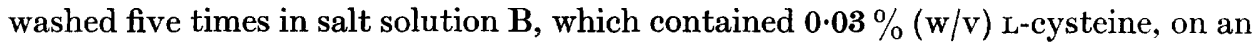
angle-head centrifuge for $\mathbf{4 5} \mathrm{sec}$. from starting. The maximum speed was equivalent to $300 \mathrm{~g}$. The organisms were finally inoculated at a population density of 100,000 $\mathbf{2 5 0}, 000 / \mathrm{ml}$. incubation medium.

Incubation conditions for incorporation experiments. Except where otherwise stated, the basal medium consisted of $1 \cdot 0-2 \cdot 0 \mathrm{ml}$. (chosen so that the final volume was $4.0 \mathrm{ml}$.) salt solution B (Coleman, $1960 \mathrm{~b}$ ) autoclaved $\left(115^{\circ}\right.$ for $20 \mathrm{~min}$.) with $0.8 \mathrm{ml}$. water, $1.5 \mathrm{ml} .2 \%$ soluble starch (dissolved in salt solution B) and glycine (when added at the beginning of the experiment) in a 5 in. $\times \frac{1}{2}$ in. cotton-plugged test tube. Immediately after removal from the autoclave and cooling, the following additions were made aseptically: $0.1 \mathrm{ml} .1 \%$ L-cysteine hydrochloride (neutralized and Seitz filtered), $0 \cdot 1 \mathrm{ml} .5 \% \mathrm{NaHCO}_{3}$ (Seitz filtered), $0 \cdot 2 \mathrm{ml}$. penicillin G (25,000 units $/ \mathrm{ml}$.), $0.2 \mathrm{ml} .1 \%$ neomycin sulphate solution, $0.2 \mathrm{ml}$. autoclaved rumen fluid residue (AR) and any other additions. After inoculation, the tubes were gassed for 10 sec. with $95 \%(\mathrm{v} / \mathrm{v}) \mathrm{N}_{2}+5 \%(\mathrm{v} / \mathrm{v}) \mathrm{CO}_{2}$, sealed with a sterile rubber bung and incubated at $39^{\circ}$. Where larger quantities of protozoa were required 5-10 times these quantities were used. For experiments on the metabolism of carbohydrates the soluble starch was omitted and for experiments on the incorporation of ${ }^{14} \mathrm{C}$ from $\mathrm{NaH}^{14} \mathrm{CO}_{3}$ the $\mathrm{NaHCO}_{3}$ was omitted and the tubes gassed with $100 \% \mathrm{~N}_{2} \cdot{ }^{14} \mathrm{C}$ glucose and $\mathrm{NaH}^{14} \mathrm{CO}_{3}$ were always added immediately before the tube was sealed. At the end of experiments where the uptake of a ${ }^{14} \mathrm{C}$-compound was investigated the protozoa were centrifuged and washed twice at $300 \mathrm{~g}$ for $1 \mathrm{~min}$. in salt solution $\mathrm{B}$ containing about $0.005 \%$ of the ${ }^{12} \mathrm{C}$ form of the ${ }^{14} \mathrm{C}$-compound added initially.

Bacterial viable counts. These were carried out on media $\mathbf{A}$ and $\mathrm{C}$ as described by Coleman (1962). The number of viable bacteria inside each protozoon was determined after breakage of washed protozoa in a Potter (Potter \& Elvehjem, 1936) homogenizer. The number of protozoa was estimated by the method of Coleman (1958). Only those protozoa which showed no signs of disintegration were counted.

Sterile rumen fuid fractions. All rumen fluid was taken from Clun Forest wethers fed on hay and oats. Protozoa-containing autoclaved rumen fluid (PARF) was prepared from fresh rumen contents by straining through two layers of muslin and autoclaving under $95 \%(\mathrm{v} / \mathrm{v}) \mathrm{N}_{2}+5 \%(\mathrm{v} / \mathrm{v}) \mathrm{CO}_{2}$ in sealed McCartney bottles at $115^{\circ}$ for $20 \mathrm{~min}$. Autoclaved rumen fluid (ARF) was prepared similarly to PARF except that the strained material was centrifuged at $500 \mathrm{~g}$ for $3 \mathrm{~min}$. before autoclaving. Autoclaved residue (AR) was the pellet from the above centrifugation resuspended in $15 \%$ of the original volume and autoclaved at $115^{\circ}$ for 20 min.

Estimation of ${ }^{14} \mathrm{C} .{ }^{14} \mathrm{C}$ in whole protozoa was estimated by washing the organisms with water on to an aluminium disc of area $4.7 \mathrm{~cm}_{.}{ }^{2}$ carrying a disc of lens tissue. 
The sample was spread by one drop of cetyltrimethyl-ammonium bromide solution $(5 \mathrm{mg} . / \mathrm{ml}$.) and fixed by one drop of polyvinyl alcohol $(2 \mathrm{mg} . / \mathrm{ml}$.). The disc was dried in vacuo and the ${ }^{14} \mathrm{C}$ estimated by using a thin mica end-window GM tube and conventional scaler equipment. Over 1000 counts at a rate greater than five times background were recorded for all fractions. Most determinations were carried out with less than $0.5 \mathrm{mg}$. of material per $\mathrm{cm}^{2}$ of disc. Where more material was present, the results were corrected to infinite thinness by using corrections determined from adding known weights of glycine, mineral salts or rumen fluid fractions to tracer quantities of ${ }^{14} \mathrm{C}$-glycine. The amount of glycine incorporated by protozoa was calculated from the known specific activity (usually 1.0-4.0 $\mu \mathrm{C}$. $/ \mathrm{mg}$.) of glycine added initially. To determine the relative ${ }^{14} \mathrm{C}$ contents of spots on a chromatogram a thin mica end-window GM tube was placed directly on the spot, the position of which had been determined by radioautography. ${ }^{14} \mathrm{CO}_{2}$ was estimated by the method of Coleman (1956).

Fractionation of organisms. The protozoa after harvesting, washing as described above and resuspension in a small volume of salt solution, were first broken by treatment in an all-glass Potter homogenizer at room temperature until 98-100\% of the protozoa were broken (usually about $90 \mathrm{sec}$.) and then homogenate made up to a known volume and centrifuged at $7000 \mathrm{~g}$ for $20 \mathrm{~min}$. The supernatant liquid from this centrifugation is hereafter referred to as the 'broken-cell supernatant fluid' and the pellet after washing once in water as the 'broken-cell pellet'. This latter fraction contained all the viable bacteria in the homogenate.

These two fractions were further fractionated by a method based on that of Schneider (1945) and Roberts et al. (1955). The fraction was treated with $5 \%$ trichloroacetic acid (TCA) and allowed to stand at $4^{\circ}$ for $30 \mathrm{~min}$. The precipitate was centrifuged down and washed once with $5 \%$ TCA. The supernatant fluid and the washing formed the 'cold TCA soluble fraction'. The precipitate was then extracted with $5 \% \mathrm{TCA}$ at $100^{\circ}$ for $30 \mathrm{~min}$. The residue was centrifuged down and washed once with $5 \%$ TCA. The supernatant fluid and washings formed the 'hot TCA soluble or nucleic acid fraction'. The TCA was removed from both fractions by washing three times with ether before plating out for the estimation of ${ }^{14} \mathrm{C}$. The residue after further washing, once with acidified ethanol and once with ether, formed the protein fraction.

The complete acid hydrolysis of any fraction was done by heating to $105^{\circ}$ in $6 \mathrm{~N}-\mathrm{HCl}$ for $16 \mathrm{hr}$ in a sealed tube. At the end of this period the tube was cooled and opened and the acid removed on a boiling water bath in a current of air.

Paper chromatography. The following solvents were used: A, sec-butanol + formic acid + water $(70+10+20$, by vol.); B, phenol + ammonia (sp.gr. $0 \cdot 880)+$ water $(80$ g. $+0 \cdot 3 \mathrm{ml} .+20 \mathrm{ml}$; Roberts et al. 1955$)$; C, $n$-propanol + ethyl acetate + water $(24+13+7$, by vol.); $\mathrm{D}, n$-butanol saturated with $1 \%(\mathrm{w} / \mathrm{v})$ aqueous ethylamine (Elsden \& Lewis, 1953); $\mathrm{E}, n$-butanol + ethanol + water $(10+1+2$ by vol.); F, $n$ butanol + acetone + water + diethylamine $(10+10+5+2$, by vol.; Hardy, Holland \& Nayler, 1955); G, isopropanol + $\mathrm{HCl}$ solution (sp.gr. $=1 \cdot 18)+$ water $(162+42+46$, by vol.); $\mathrm{H}, n$-butanol + cyclohexane + propylene glycol + water $+\mathrm{NH}_{4} \mathrm{OH}$ (sp.gr. $=0 \cdot 880)+$ morpholine $(30+30+10+3 \cdot 5+0 \cdot 7+0 \cdot 07$, by vol.; Guillaume $\&$ Osteux, 1955); J, benzene + isopropanol + propylene glycol + water $+\mathrm{NH}_{4} \mathrm{OH}$ (sp.gr. = $0 \cdot 880)(30+20+10+3+0 \cdot 6$, by vol.; Guillaume \& Osteux, 1955). 
Protein hydrolysates were chromatographed in two dimensions in solvents $\mathrm{A}$ and B (Roberts et al. 1955).

Purification of glycine- $X$. The method finally adopted was as follows. The supernatant fluids obtained after incubation of protozoa for 3 days in the standard medium containing $0.05 \mathrm{M}{ }^{12} \mathrm{C}$-glycine or tracer $\left[\mathrm{u}^{14} \mathrm{C}\right]$ glycine were combined and shaken with Zeo Karb $225\left(\mathrm{H}^{+}\right)$and the resin discarded. The supernatant fluid was neutralized with $8 \% \mathrm{Ba}(\mathrm{OH})_{2}$ and the precipitate centrifuged down. Glycine-X was then absorbed on to a column of Dowex $2\left(\mathrm{OH}^{-}\right)$which was then washed successively with water, N-acetic acid, water. Glycine-X was then eluted with $\mathrm{N}-\mathrm{HCl}$ and the eluate evaporated to dryness in vacuo. The material was further purified by chromatography in solvent $\mathbf{A}$ and its position determined by radioautography. The spot was eluted and this material used for analytical tests.

Estimation of soluble glycine in protozoa. Washed protozoa were broken in a Potter homogenizer and the homogenate centrifuged at $7000 \mathrm{~g}$ for $20 \mathrm{~min}$. Free glycine was then estimated in the supernatant fluid, after the removal of protein with tungstic acid, by the method of Alexander, Landwehr \& Seligman (1945). Combined and free glycine were estimated together after hydrolysis of the proteinfree supernatant in $6 \mathrm{~N}-\mathrm{HCl}$ for $16 \mathrm{hr}$ at $105^{\circ}$ in a sealed tube.

Chemicals. ${ }^{14} \mathrm{C}$-compounds were supplied by the Radiochemical Centre, Amersham, Buckinghamshire. All the compounds were uniformly labelled except for $\left[1^{-14} \mathrm{C}\right]$ sodium acetate. The specific activity of the compounds as supplied was in $\mu \mathrm{C}$. per mg. : glucose 450 , glycine 41 , maltose 16 , sodium acetate 260 , sodium carbonate 250 , starch 23. The specific activity of these compounds was usually lowered to a more convenient level by the addition of carrier ${ }^{12} \mathrm{C}$-compound before use. $\mathrm{N}$-Acetylglycine was supplied by L. Light and Co. Ltd.

\section{RESULTS}

\section{Metabolism of glycine}

Washed suspensions of Entodinium caudatum prepared from growing cultures and incubated anaerobically in the presence of soluble starch, penicillin and neomycin incorporated ${ }^{14} \mathrm{C}$-glycine. Initially each protozoon contained $10-100$ viable bacteria in its gastric sac and there were 10-20 viable bacteria/protozoon free in the medium as determined by growth on media $\mathrm{A}$ and $\mathrm{C}$ (Coleman, 1962). The number of viable bacteria in these cultures measured immediately after inoculation was only $10 \%$ of that found previously (Coleman, 1962). This finding is probably associated with the addition of less rice starch each day to the protozoal cultures and the use of lower centrifuge speeds when washing the protozoa. When the basal medium was supplemented by $5 \%$ autoclaved residue (AR) $80-100 \%$ of the protozoa survived for over 3 days compared with $\mathbf{4 0} \%$ in its absence, during which time the bacterial viable count on the complete medium decreased to $10 \%$ of the initial. Figure 1 shows that ${ }^{14} \mathrm{C}$-glycine added to the culture at any time during the first $24 \mathrm{hr}$ was incorporated into the protozoal fraction although the initial rate and the final level of incorporation dropped the later the glycine was added.

Effect of salt concentration and rumen fluid fractions. The concentration of salts in the medium had a marked effect on the incorporation of glycine measured after incubation for $7 \mathrm{hr}$ although there was no effect on the number of apparently 
healthy protozoa over this time and only a small effect over $48 \mathrm{hr}$. The uptake of ${ }^{14} \mathrm{C}$-glycine was stimulated by the addition of $10 \%$ of all the rumen fluid fractions tested of which $10 \%$ AR was the most effective (Fig. 2). However, the magnitude of this stimulation with AR varied from $380 \%$ in salt solution $\mathrm{B}$ to $55 \%$ in salt solution $\mathrm{B}$ diluted by $20 \%$. AR was therefore added to all media for incorporation experiments. Control experiments carried out in the absence of protozoa showed that there was no adsorption of ${ }^{14} \mathrm{C}$ on to the particles of AR. The supernatant obtained after centrifugation of AR had only 10-20\% of the incorporation-promoting activity of the original material.

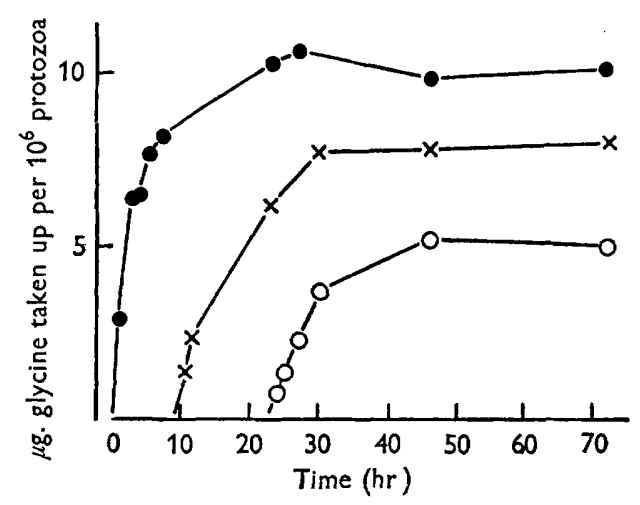

Fig. 1

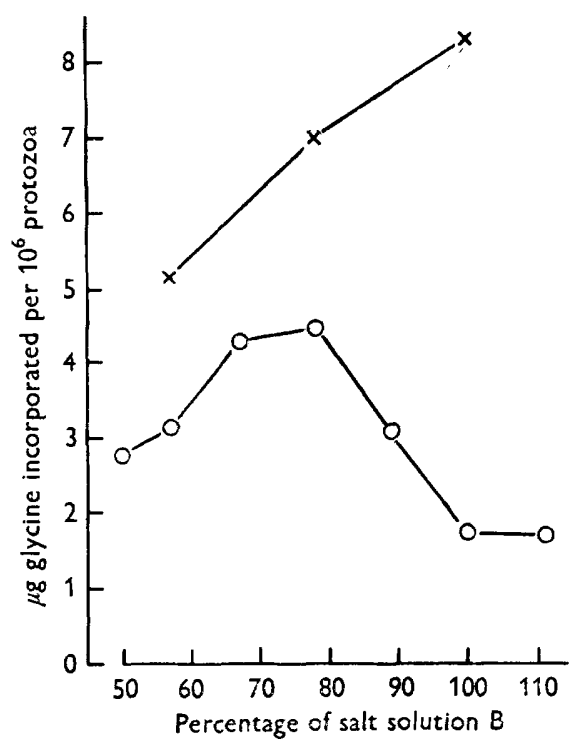

Fig. 2

Fig. 1. Incorporation of glycine into Entodinium caudatum incubated in presence of penicillin and neomycin. $-\longrightarrow, 28 \mu \mathrm{g}{ }^{14} \mathrm{C}$-glycine/ml. added initially; $\times \longrightarrow \times, 28 \mu \mathrm{g}$ ${ }^{14} \mathrm{C}$-glycine $/ \mathrm{ml}$. added after $9 \frac{1}{2} \mathrm{hr} ; \mathrm{O}-\mathrm{O}, 28 \mu \mathrm{g}$. ${ }^{14} \mathrm{C}$-glycine $/ \mathrm{ml}$. added after $23 \mathrm{hr}$. Results calculated from uptake of ${ }^{14} \mathrm{C}$ from ${ }^{14} \mathrm{C}$-glycine of specific activity 130 counts/ $\min . / \mu \mathrm{g}$.

Fig. 2. Effect of salt concentration on incorporation of ${ }^{14} \mathrm{C}$-glycine during the first $7 \mathrm{hr}$ of incubation. The concentration of cysteine, $\mathrm{NaHCO}_{3}$, penicillin and neomycin were maintained constant throughout and only the concentration of the constituents of salt solution $B$ varied. $O-O$, no addition; $x-\times,+10 \%$ autoclaved residue (AR).

Effect of glycine concentration. To determine whether the glycine incorporated by the protozoa was free in the gastric sac, the protozoa were incubated with various concentrations of $\left[\mathrm{u}^{-14} \mathrm{C}\right]$ glycine and the uptake measured. At the lowest concentrations of glycine (up to $20 \mu \mathrm{g}$. $/ \mathrm{ml}$. in the presence of $2 \times 10^{5}$ protozoa $/ \mathrm{ml}$.) over $7 \%$ of the total ${ }^{14} \mathrm{C}$ was taken up in $4 \mathrm{hr}$ by organisms, the packed cell pad volume of which was less than $1 \%$ of the total. This shows that glycine was concentrated inside the protozoa. At low external glycine concentrations most of the non-protein glycine was in a combined form, but as the external concentration was increased there was a marked increase in the amount of free glycine present (Fig. 3). It is possible that some of this glycine was not intracellular but was present in the 
gastric sac, as the method used does not separate glycine in the cell 'pool' from that in the gastric sac.

Effect of antibiotics and breakage of the protozoa. Although the above results show that glycine was incorporated into the micro-organisms in the suspensions, this uptake might have been into the extracellular or intracellular bacteria rather than into the protozoal protoplasm. In an attempt to eliminate this possibility the uptake of ${ }^{14} \mathrm{C}$-glycine by intact protozoa was compared with that obtained with protozoa which had been broken under conditions that did not break the bacteria, i.e. in a Potter homogenizer. As a further test for the possible uptake of ${ }^{14} \mathrm{C}$-glycine into bacteria, all the experiments were done in duplicate; one tube was centrifuged under

\section{Table 1. Incorporation of ${ }^{14} \mathrm{C}$-glycine by broken and intact Entodinium caudatum in the presence and absence of antibiotics}

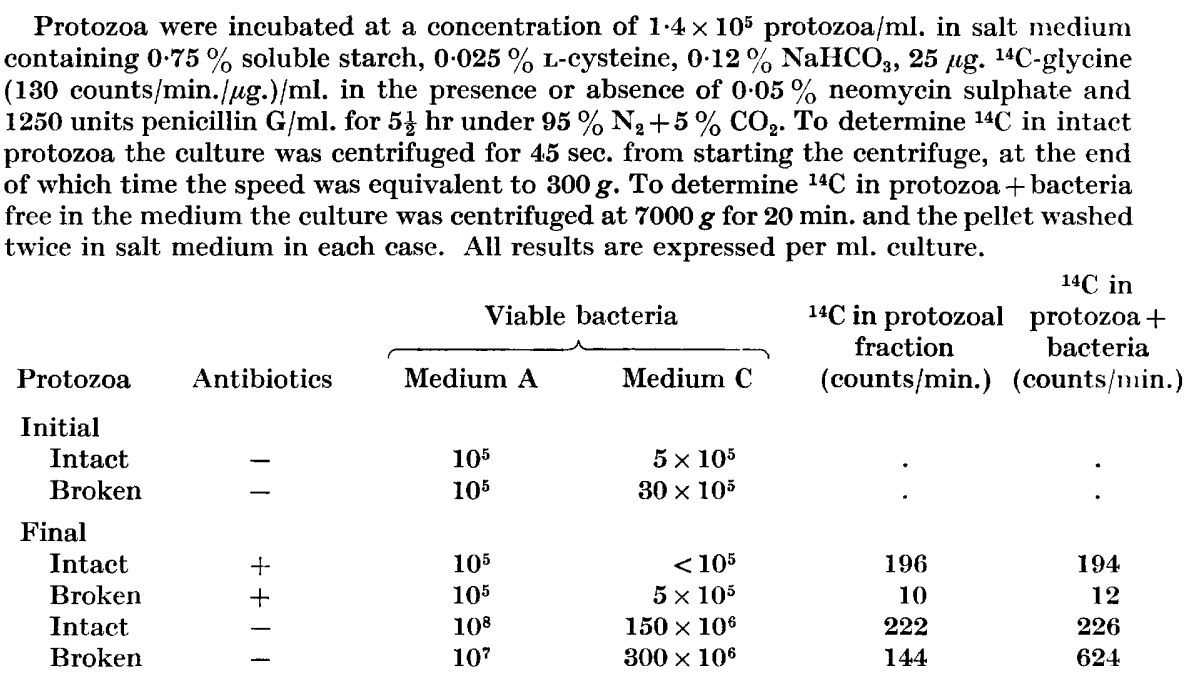

* The viable counts were carried out on media A and $\mathrm{C}$ respectively (Coleman, 1962).

conditions such that only protozoa were sedimented (45 sec. at up to $300 \mathrm{~g}$ ) and the other such that protozoa + free bacteria were sedimented $(20 \mathrm{~min}$. at $7000 \mathrm{~g})$. Table 1 shows that in the presence of antibiotics breakage of the protozoa decreased the incorporation into the protozoal fraction to $5 \%$ and that the same result was obtained under both sets of sedimentation conditions, indicating that uptake by intracellular and extracellular bacteria was negligible. In the absence of antibiotics there was an increase (range 10-100\% depending on the experiment) in the incorporation by intact protozoa. However, the experiments made in the absence of antibiotics are difficult to interpret due to the rapid bacterial growth under these conditions.

Intracellular products of glycine metabolism. As a further test as to whether the uptake of ${ }^{14} \mathrm{C}$-glycine was into the bacteria, protozoal suspensions which had incorporated glycine were broken in a Potter homogenizer. The homogenate was then centrifuged to produce a supernatant fraction free of bacteria and a pellet fraction which contained all the bacteria. Table 2 shows that after $1 \mathrm{hr}$ incubation in the 
presence of ${ }^{14} \mathrm{C}$-glycine over $80 \%$ of the ${ }^{14} \mathrm{C}$ incorporated into intact protozoa was present in the broken-cell supernatant fluid and that $88 \%$ of that was in the cold $5 \%$ TCA soluble or small molecular weight fraction. The low incorporation of ${ }^{14} \mathrm{C}$ into the pellet shows that less than $20 \%$ of the total incorporation could have been into the bacteria. Incubation in the absence of antibiotics resulted in a tenfold increase in the ${ }^{14} \mathrm{C}$ in the pellet fraction and this was probably due to increased incorporation by the intracellular bacteria which were present in this fraction; the incorporation into the supernatant fraction was unchanged.

\title{
Table 2. Distribution of ${ }^{14} \mathrm{C}$ in Entodinium caudatum during the incorporation of ${ }^{14} \mathrm{C}$-glycine
}

\begin{abstract}
Protozoa were incubated at a concentration of $3.5 \times 10^{5}$ protozoa $/ \mathrm{ml}$. in $8 \mathrm{ml}$. salt medium containing $0.75 \%$ soluble starch, $0.025 \%$ L-cysteine, $0.12 \% \mathrm{NaHCO}_{3}, 0.05 \%$ neomycin sulphate, 1250 units penicillin $\mathrm{G} / \mathrm{ml}$. and $28 \mu \mathrm{g}$. ${ }^{14} \mathrm{C}$-glycine $(440$ counts $/ \mathrm{min}$. $\mu \mathrm{g}$.) $/ \mathrm{ml}$. under $95 \% \mathrm{~N}_{2}+5 \% \mathrm{CO}_{2}$. One $8 \mathrm{ml}$. tube was harvested for each time point. All results are expressed in counts/min.
\end{abstract}

\begin{tabular}{|c|c|c|c|c|c|c|}
\hline \multirow[b]{2}{*}{$\begin{array}{l}\text { Time } \\
\text { (hr) }\end{array}$} & \multicolumn{3}{|c|}{ Broken-cell supernatant fluid } & \multicolumn{3}{|c|}{ Broken-cell pellet } \\
\hline & $\begin{array}{l}\text { Cold TCA } \\
\text { soluble }\end{array}$ & $\begin{array}{l}\text { Hot TCA } \\
\text { soluble }\end{array}$ & $\begin{array}{l}\text { Protein } \\
\text { (counts }\end{array}$ & $\begin{array}{l}\text { Cold TCA } \\
\text { soluble } \\
\text { in.) }\end{array}$ & $\begin{array}{l}\text { Hot TCA } \\
\text { soluble }\end{array}$ & Protein \\
\hline 1 & 1710 & 64 & 140 & 95 & 123 & 180 \\
\hline $5 \frac{1}{2}$ & 2170 & 168 & 580 & 230 & 232 & 380 \\
\hline 23 & 1120 & 160 & 1440 & 110 & 76 & 700 \\
\hline
\end{tabular}

In antibiotic-treated cultures all the protein ${ }^{14} \mathrm{C}$ was present as glycine. This was determined by chromatography in solvents $\mathrm{A}, \mathrm{B}, \mathrm{C}, \mathrm{D}$ and $\mathrm{E}$ and by the fingerprint method of Roberts et al. (1955). Solvent F separated glycine and serine better than the other solvents and no trace of ${ }^{14} \mathrm{C}$ was found at the $\boldsymbol{R}_{F}$ of the serine marker. The cold TCA-soluble material from the supernatant fraction prepared from protozoa incubated in the presence or absence of antibiotics contained only one ${ }^{14} \mathrm{C}$-component at low external glycine concentrations and this had different chromatographic properties from glycine (see below).

Extracellular products of glycine metabolism. Figure 1 shows that although glycine uptake apparently proceeded for only $24 \mathrm{hr}$ when glycine was added initially, glycine first added after $24 \mathrm{hr}$ was still incorporated. This suggested that the amount of ${ }^{14} \mathrm{C}$ found in the protozoa at any time may have represented a balance between the uptake of glycine and the liberation of glycine or a glycine metabolite by the organisms. To test this theory the following experiments were carried out.

Protozoa were incubated under otherwise identical standard conditions in tubes containing: (a) $3 \mu$ mole ${ }^{12} \mathrm{C}$-glycine $+0 \cdot 2 \mu \mathrm{C}$. ${ }^{14} \mathrm{C}$-glycine; $(b) 3 \mu$ mole ${ }^{12} \mathrm{C}$-glycine; $(c)$ no glycine. When the rate of ${ }^{14} \mathrm{C}$ incorporation in tube $(a)$ began to decrease, i.e. after $10 \mathrm{hr}, 0 \cdot 2 \mu \mathrm{C} .{ }^{14} \mathrm{C}$-glycine was added to tube $(b)$ and $3 \mu$ mole ${ }^{12} \mathrm{C}$-glycine and $0 \cdot 2 \mu \mathrm{C} .{ }^{14} \mathrm{C}$-glycine to tube $(c)$. The rate and total uptake of ${ }^{14} \mathrm{C}$ was the same in tubes (b) and (c). Similar results were obtained when the additions were made after $24 \mathrm{hr}$. This shows that even when there was an equilibrium amount of ${ }^{12} \mathrm{C}$-glycine in the protozoa, uptake of glycine, presumably balanced by an equivalent loss of 'glycine', still occurred.

In an attempt to demonstrate this loss of glycine an excess of ${ }^{12} \mathrm{C}$-glycine was 
added to protozoa that contained an amount of ${ }^{14} \mathrm{C}$-glycine in equilibrium with ${ }^{14} \mathrm{C}$-glycine in the medium. Under these conditions decrease in the specific activity of the medium glycine to about $10 \%$ of the initial value decreased the ${ }^{14} \mathrm{C}$ in the protozoa by $50 \%$ after $7 \mathrm{hr}$. In the absence of any added ${ }^{12} \mathrm{C}$-glycine there was no loss of ${ }^{14} \mathrm{C}$. This shows that when the rate of uptake of ${ }^{14} \mathrm{C}$ was decreased by lowering the specific activity of the medium glycine, then the protozoa lost ${ }^{14} \mathrm{C}$ presumably due to the liberation of high specific activity 'glycine'. If the plateau in the glycine incorporation were due to the inability of the protozoa to take up further glycine, then this loss would not have occurred. The addition of equivalent amounts of L-alanine, L-aspartic acid or sarcosine produced no fall in the protozoal ${ }^{14} \mathrm{C}$.

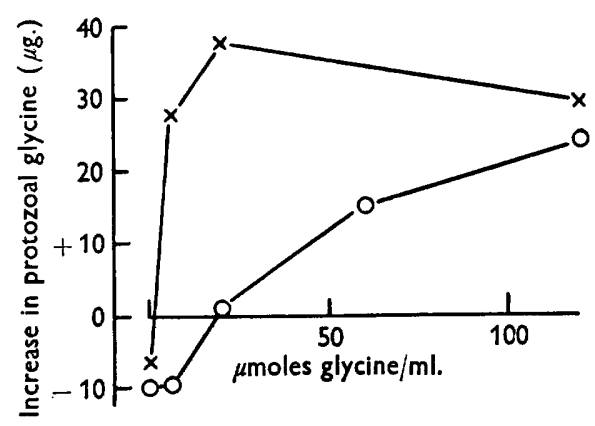

Fig. 3

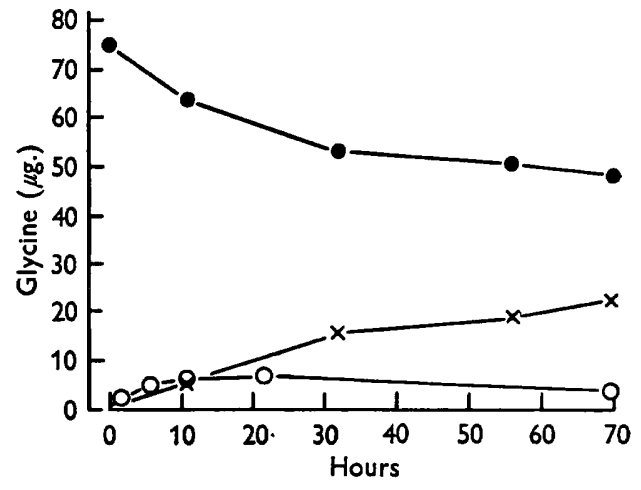

Fig. 4

Fig. 3. Effect of glycine concentration on the amount of free $(\mathrm{O}-\mathrm{O})$ and combined $(\times-\times)$ glycine present in Entodinium caudatum after removal of protein. The results are expressed per $9 \cdot 26 \times 10^{5}$ protozoa which were incubated in $5 \mathrm{ml}$. medium for $6 \mathrm{hr}$. The initial glycine amounts were: free 10.2 $\mu \mathrm{g}$.; combined $15.5 \mu \mathrm{g}$.

Fig. 4. Metabolism of glycine by Entodinium caudatum. $\bigcirc-\bigcirc$, glycine incorporated into protozoa; - - , free glycine in the supernatant fluid; $\times \frac{-}{-}$, glycine-metabolite in supernatant fluid. Results calculated from uptake of ${ }^{14} \mathrm{C}$ from ${ }^{14} \mathrm{C}$-glycine $(440$ counts $/ \mathrm{min} . / \mu \mathrm{g}$.) by $1.34 \times 10^{6}$ protozoa suspended in $10 \mathrm{ml}$. medium.

It was not possible to demonstrate a glycine-induced loss of ${ }^{14} \mathrm{C}$ from washed equilibrium-state protozoa because after washing once in salts $0.02 \% \mathrm{~L}$-cysteine medium and resuspension in the standard medium, the protozoa lost $50 \%$ of their ${ }^{14} \mathrm{C}$ in $7 \mathrm{hr}$ in the absence of external glycine. The rate of ${ }^{14} \mathrm{C}$ release under these conditions was the same at $38^{\circ}, 3^{\circ}, 2^{\circ}$ and $20^{\circ}$. That this was not the result of damage to the protozoa was shown by the finding that washed equilibrium-state protozoa inoculated into medium containing glycine of the same specific gravity as that present in the first incubation medium lost no ${ }^{14} \mathrm{C}$.

Chromatographic separation of the materials present in the incubation medium from equilibrium-state protozoa revealed two ${ }^{14} \mathrm{C}$ spots only. One was glycine and the other ran with the same $\boldsymbol{R}_{F}$ as $(a){ }^{14} \mathrm{C}$-material found in the cold TCA-soluble fraction from the broken-cell supernatant fluid, and $(b)$ the material liberated from equilibrium-state protozoa by ${ }^{12} \mathrm{C}$-glycine or washing. The amount of this material increased throughout the incubation and could account for $30 \%$ of the ${ }^{14} \mathrm{C}$-glycine added initially (Fig. 4). This unknown material was also produced when the sodium 
propionate in the medium was replaced by an equimolar amount of sodium acetate or sodium chloride.

The composition of the glycine-metabolite. Preliminary experiments carried out with incubation media taken after 3 days showed that this material was not absorbed by Zeo Karb $225\left(\mathbf{H}^{+}\right)$which removed free glycine, but was absorbed by Dowex $2\left(\mathrm{OH}^{-}\right)$from which it was eluted by $\mathrm{N}-\mathrm{HCl}$ but not by $\mathrm{N}$-acetic acid; this shows that the metabolite was a comparatively strong acid. By using a method based on these properties considerable purification was achieved. The ${ }^{14} \mathrm{C}$-material in the final eluate was chromatographed in solvent $\mathbf{A}$ where it ran as a discrete spot with $\boldsymbol{R}_{F}$ value $\mathbf{0} \cdot 9$. This spot, which was detected by radioautography or by spraying with bromocresol green, was eluted, found to be a single spot when chromatographed in solvents A, B, C, D, E, J, and analysed.

After complete acid hydrolysis, the material was chromatographed in two dimensions in solvents $\mathrm{A}$ and $\mathrm{B}$. The only ${ }^{14} \mathrm{C}$ - and ninhydrin-positive spot was glycine. When $0.5 \%$ collidine was incorporated in the ninhydrin spray the spot had the characteristic glycine colour. The absence of serine was shown by chromatography in solvent F. However, the same quantity of the unhydrolysed material, after chromatography in solvent $A$, was ninhydrin negative, indicating the probable absence of a free amino group, contained no phosphate as shown by spraying with molybdate + perchloric acid (Bandurski \& Axelrod, 1951) and no carbohydrate as shown by spraying with aniline + oxalate (Horrocks \& Manning, 1949).

These properties suggested that the glycine metabolite might be a compound such as an $N$-acylglycine, possibly $N$-acetylglycine. The unknown material was chromatographed in solvents $A, B, C, D, F, H$ and $J$ and shown to run with the same $R_{F}$ as marker $N$-acetyl glycine, which was detected by spraying with bromocresol green, in all solvents. The unknown had different chromatographic properties from $N$-formylglycine in solvents $\mathrm{A}$ and $\mathrm{J}$. To obtain satisfactory results it was essential to adjust the unknown material and the $N$-acetylglycine to the same $\mathrm{pH}$ value before developing the chromatograms. The glycine metabolite prepared from tracer quantities of ${ }^{14} \mathrm{C}$-glycine only also corresponded with $\mathrm{N}$-acetylglycine by the fingerprint technique of Roberts et al. (1955) after chromatography in solvents A and B.

The presence of an acetyl group in the glycine metabolite was shown in the following way. The protozoa were incubated for $\mathbf{3}$ days under standard conditions in the presence of $0.02 \mathrm{M}^{-12} \mathrm{C}$-glycine and $1.44 \mu \mathrm{g}\left(0.4 \mu \mathrm{C}\right.$.) ${ }^{1-14} \mathrm{C}$-sodium acetate $/ \mathrm{ml}$. The metabolite in the medium was purified and finally chromatographed in solvent $\mathbf{J}$ (opposite $\mathrm{N}$-acetylglycine). The ${ }^{14} \mathrm{C}$ spot was eluted, shown to have the same chromatographic properties as $N$-acetylglycine in solvents $\mathrm{A}, \mathrm{B}, \mathrm{H}$ and $\mathrm{J}$, hydrolysed in $\mathrm{N}-\mathrm{NaOH}$ for $2 \mathrm{hr}$ and finally chromatographed, without removal of the alkali, in solvent $\mathrm{H}$ which separates the lower fatty acids. The ${ }^{14} \mathrm{C}$ material which was acid volatile chromatographed with the same $\boldsymbol{R}_{F}$ as marker sodium acetate.

\section{Incorporation of ${ }^{14} \mathrm{C}$ from ${ }^{14} \mathrm{C}$-bicarbonate}

${ }^{14} \mathrm{C}$ (added to the medium as $\mathrm{NaH}^{14} \mathrm{CO}_{3}$ ) was incorporated linearly by Entodinium caudatum for $10 \mathrm{hr}$ (Fig. 5) before the uptake reached a plateau. The addition of further $\mathrm{NaH}^{14} \mathrm{CO}_{3}$ at 10 or $24 \mathrm{hr}$ in order approximately to double the original specific activity (of the $\mathrm{CO}_{2}$ ) produced a further incorporation of ${ }^{14} \mathrm{C}$. Diminution in the specific activity of the $\mathrm{CO}_{2}$ to approximately $20 \%$ of that of the original ${ }^{14} \mathrm{CO}_{2}$ 
by the addition of $\mathrm{NaH}^{12} \mathrm{CO}_{3}$ at $10 \mathrm{hr}$ produced a small decrease in the ${ }^{14} \mathrm{C}$ in the protozoa, but the effect was smaller than in the case of glycine. As there was a uniform increase in the amount of non-volatile ${ }^{14} \mathrm{C}$-material in the medium over $24 \mathrm{hr}$ these results suggested that ${ }^{14} \mathrm{C}$ was incorporated by the protozoa and then liberated again into the medium.

The ${ }^{14} \mathrm{C}$ uptake was dependent on the presence of intact protozoa and breakage of the protozoa reduced it by over $90 \%$. The results obtained in the presence and absence of antibiotics with protozoa harvested at the end of the incubation by highor low-speed centrifugation were similar to those obtained with glycine.

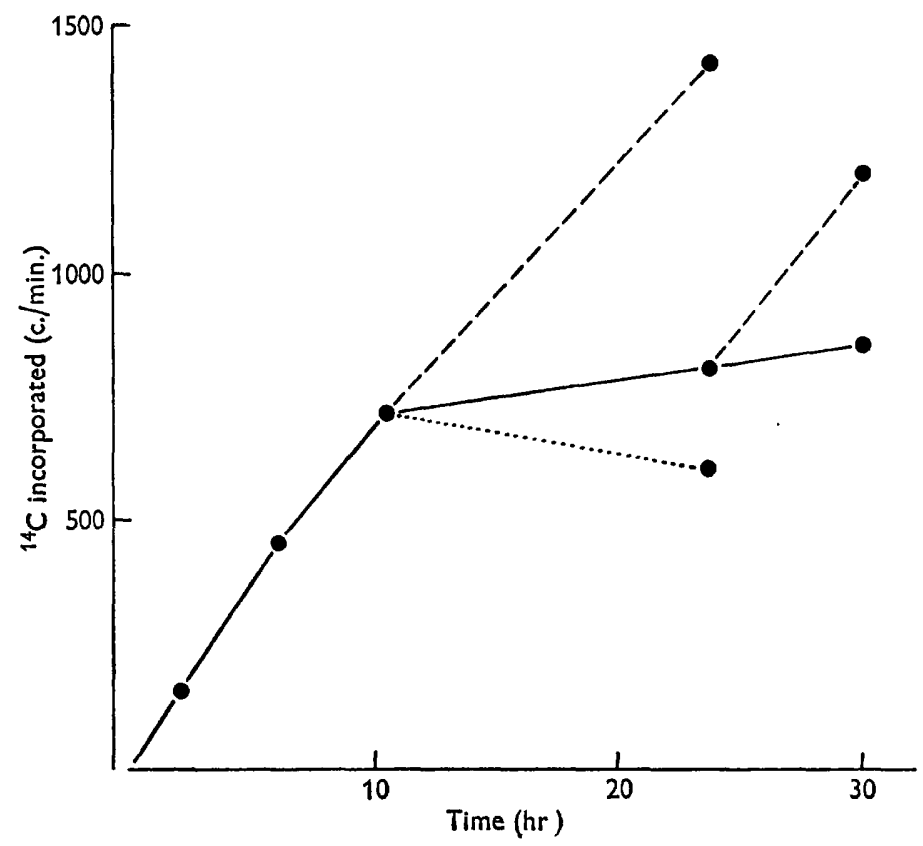

Fig. 5. Incorporation of ${ }^{14} \mathrm{C}$ into Entodinium caudatum incubated $\longrightarrow$ in presence of $\mathrm{NaH}^{14} \mathrm{CO}_{3}(100 \mu \mathrm{g}$. and 4000 counts $/ \mathrm{min}$. $/ \mathrm{ml}$. $)$. - -, Additional $\mathrm{NaH}^{14} \mathrm{CO}_{3}(0 \cdot 2 \mu \mathrm{g}$. and 4000 counts $/ \mathrm{min} . / \mathrm{ml}$.) added; $\cdots \cdot, 500 \mu \mathrm{g} . / \mathrm{ml} . \mathrm{NaH}^{12} \mathrm{CO}_{3}$ added.

Table 3 shows that over $60 \%$ of the ${ }^{14} \mathrm{C}$ incorporated from $\mathrm{NaH}^{14} \mathrm{CO}_{3}$ was found in the hot TCA-soluble fraction of the broken-cell pellet. After removal of the TCA with ether the material was hydrolysed in $\mathrm{N}-\mathrm{HCl}$ for $1 \mathrm{hr}$ at $100^{\circ}$ and chromatographed in solvent $\mathrm{G}$. The ${ }^{14} \mathrm{C}$ material, which ran as a single spot, as detected by radioautography, did not correspond with any nucleic acid components as detected by ultraviolet photography. The spot was eluted and identified in the following way. When ${ }^{12} \mathrm{C}$-glucose was added to the ${ }^{14} \mathrm{C}$ material and an osazone prepared the ${ }^{14} \mathrm{C}$ was found in the precipitated osazone, indicating that the ${ }^{14} \mathrm{C}$ material was glucose or fructose. This material also gave the characteristic hexose reaction when treated with aniline oxalate reagent (Horrocks \& Manning, 1949). Chromatography against markers in solvents $\mathbf{A}, \mathbf{B}, \mathbf{C}, \mathbf{E}, \mathbf{G}$ and $\mathbf{H}$ indicated that the unknown material was glucose which was probably present in the intact protozoon as starch. As confirmation of its identity the unknown material was chromatographed in solvent $\mathbf{E}$ before and after treatment with glucose oxidase. As a result of enzyme action the original 
spot disappeared and was replaced by another which ran with the same $\boldsymbol{R}_{F}$ as that produced from pure ${ }^{14} \mathrm{C}$-glucose under the same conditions.

To determine which of the glucose carbon atoms were labelled with ${ }^{14} \mathrm{C}$ the glucose was fermented under nitrogen by baker's yeast (Barnet \& Wick, 1950) in a Conway unit and the ${ }^{14} \mathrm{CO}_{2}$ collected on an aluminium disc containing $\mathrm{Ba}(\mathrm{OH})_{2}$ (Coleman, 1956). At the end of the reaction the baryta was dried in vacuo and the ${ }^{14} \mathrm{C}$ estimated. Under these conditions $33 \%$ of the ${ }^{14} \mathrm{C}$ in uniformly labelled glucose and $95 \%$ of the ${ }^{14} \mathrm{C}$ in glucose isolated from protozoa incubated with ${ }^{14} \mathrm{CO}_{2}$ for $\frac{1}{2}, 4$ or

\section{Table 3. Distribution of ${ }^{14} \mathrm{C}$ in Entodinium caudatum after incorporation of ${ }^{14} \mathrm{C}$-bicarbonate}

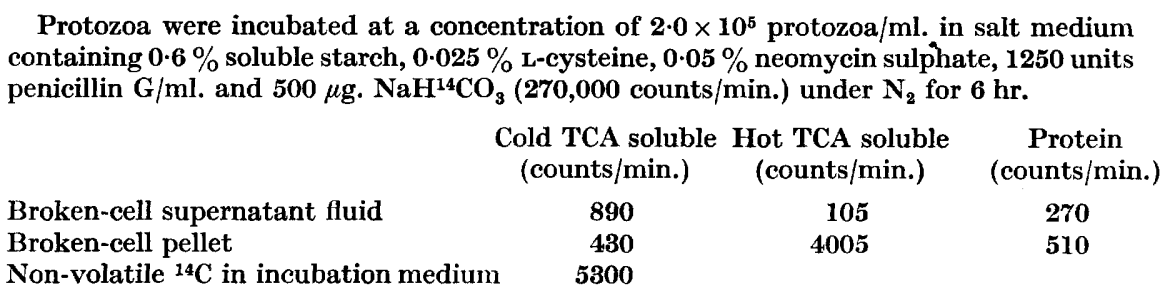

$11 \mathrm{hr}$ was liberated as $\mathrm{CO}_{2}$. As $\mathrm{CO}_{2}$ is produced only from glucose carbon atoms 3 and 4 by this method, the result shows that Entodinium caudatum was similar to higher animals (Abraham \& Hassid, 1957) in that ${ }^{14} \mathrm{C}$ from ${ }^{14} \mathrm{CO}_{2}$ was incorporated only into these carbon atoms of glucose. The protein from the supernatant fluid and pellet contained ${ }^{14} \mathrm{C}$-aspartic acid, ${ }^{14} \mathrm{C}$-glutamic acid, ${ }^{14} \mathrm{C}$-alanine and ${ }^{14} \mathrm{C}$-leucine, isoleucine or phenylalanine which were not separated by the chromatographic solvents used. Insignificant amounts of ${ }^{14} \mathrm{C}$ were found in lipid extracted by the method of Roberts et al. (1955).

Incorporation of ${ }^{14} \mathrm{C}$ from uniformly labelled ${ }^{14} \mathrm{C}$-starch, ${ }^{14} \mathrm{C}$-maltose and ${ }^{14} \mathrm{C}$-glucose . Soluble ${ }^{14} \mathrm{C}$-starch was rapidly taken up by Entodinium caudatum and the maximum incorporation was reached inside $15 \mathrm{~min}$. Thereafter the ${ }^{14} \mathrm{C}$ was slowly lost from the protozoa until only $10 \%$ remained after $24 \mathrm{hr}$. At this time over $85 \%$ of this residual ${ }^{14} \mathrm{C}$ was in the hot TCA-soluble fraction and none was present in the protein amino acids. Any starch present in the protozoa would be extracted by hot TCA and appear in that fraction. The total ${ }^{14} \mathrm{C}$ in the culture was constant over $24 \mathrm{hr}$, at which time the principal ${ }^{14} \mathrm{C}$ materials in the medium were found to be maltose and glucose. It seems probable therefore that the soluble starch was absorbed by the protozoa and then slowly hydrolysed to maltose and glucose without appreciable conversion into cellular material. Incorporation of ${ }^{14} \mathrm{C}$ from $\left[\mathrm{u}-{ }^{14} \mathrm{C}\right]$ glucose and [u-14C]maltose was small; less than $0.2 \%$ of the carbon was incorporated at sugar concentrations of I $\mu \mathrm{g} .-10 \mu \mathrm{g} . / \mathrm{ml}$. Glucose disappearance at these concentrations was also measured by the method of Huggett \& Nixon (1957) but none was detected.

\section{DISCUSSION}

Although Williams et al. (1961) and Gutierrez \& Davis (1962) showed that Ophryoscolex caudatus and Epidinium ecaudatam washed free from most of their extracellular bacteria but probably still containing bacteria in their gastric sacs, incorporated three amino acids, these authors gave no evidence that the uptake was directly into protozoal material. Although materials in the gastric sac can obviously 
be digested by a protozoon, they must be regarded as extracellular. The present studies show that at low external glycine concentrations at least, much more glycine (free and combined) was found inside the protozoa than could be accounted for by free diffusion of external medium into the gastric sac. Since after incubation for $1 \mathrm{hr}$ over $70 \%$ of the glycine had been metabolized to $\mathrm{N}$-acetylglycine and no free glycine could be detected in the broken-cell supernatant fluid, this suggests that, if the glycine entered the organism via the gastric sac, it was rapidly metabolized from it. Although this evidence and the finding that breakage of the protozoa almost completely abolished incorporation indicate that the reactions probably represent protozoal metabolism, it is impossible to be certain that the incorporation was not mediated by the bacteria in the gastric sac. It has been assumed in these studies that the material in the broken-cell supernatant fluid was of protozoal origin, but it is uncertain to what extent protozoal protein and nucleic acid were carried down with bacteria, starch and other cell debris in the pellet fraction.

The liberation of $\mathrm{N}$-acetylglycine into the medium is not considered to be the result of lysis of the protozoa because: $(a)$ as much $N$-acetylglycine was released every $7-10 \mathrm{hr}$ as was found in the protozoa at any one time (Fig. 4); (b) the number of protozoa remained constant over the period of the experiment, although this may have been the result of the death of some protozoa balanced by the division of an equal number of other protozoa; $(c)$ after washing equilibrium-state protozoa there was only a decrease in protozoal ${ }^{14} \mathrm{C}$ when the protozoa were inoculated into fresh medium containing no glycine or glycine of a lower specific activity to that used in the first incubation. The observation that $N$-acetylglycine was liberated from protozoa after washing and that the rate of release was independent of temperature suggests that the process was passive diffusion rather than active secretion. In view of the known action of penicillin on bacterial cell-wall synthesis (Park, 1958) it is of interest that $\mathrm{N}$-acetylglycine was also produced in the absence of penicillin. Although glycine is often converted into serine in mammals (Bach, 1952), some bacteria (e.g. Roberts et al. 1955) and in Tetrahymena (Dewey \& Kidder, 1955), there is no evidence for such a reaction in Entodinium caudatum.

Although the protozoa were capable of incorporating glycine into their cellular protein no evidence was obtained for the synthesis of protein amino acids from carbohydrate. The protozoa were therefore either unable to synthesize amino acids under any conditions or only when multiplying. As shown previously (Coleman, 1962) high concentrations of some carbohydrates prolonged the life of starved, almost bacteria-free protozoa. The results quoted here with protozoa containing bacteria show that if this effect was concerned with the metabolism of the carbohydrates then the proportion of the carbohydrate that was metabolized by or incorporated into the protozoa was very small. In contrast there was rapid incorporation of ${ }^{14} \mathrm{C}$ from ${ }^{14} \mathrm{C}$-bicarbonate into carbon atoms 3 and 4 of protozoal glucose, probably in the form of starch in the living organism, suggesting that the enzymes of the EmbdenMeyerhof pathway are present in these protozoa.

It is not claimed that the conclusions reached here with non-multiplying protozoa in the presence of antibiotics can be used as good evidence for the source of the amino acids required for the growth of these protozoa. However, the results do show that certain biosynthetic reactions can probably be carried out by these entodinia without assistance from their associated bacteria. 
I wish to thank Miss J. G. Pearson, Miss J. King and Miss E. V. Holgate for their valuable technical assistance.

\section{REFERENCES}

Abou Akkada, A. R. \& Howard, B. H. (1962). The biochemistry of rumen protozoa. 5. The nitrogen metabolism of Entodinium. Biochem. J. 82, 313.

Abraham, S. \& Hassid, W. Z. (1957). The synthesis and degradation of isotopically labelled carbohydrates and carbohydrate intermediates. Methods in Enzymology, Ed. by S. P. Colowick \& N. O. Kaplan, vol. 4. New York: Academic Press Ine.

Alexander, B., Landwehr, G. \& Seligman, A. M. (1945). A specific micromethod for the colorimetric determination of glycine in blood and urine. J. biol. Chem. 160, 51 .

Bach, J.S. (1952). The Metabolism of Protein Constituents in the Mammalian Body. Oxford: Clarendon Press.

Bandurski, R. S. \& Axelrod, B. (1951). The chromatographic identification of some biologically important phosphate esters. J. biol. Chem. 193, 405.

Barnet, H. N. \& Wick, A. N. (1950). The formation of glycogen from ${ }^{14} \mathrm{C}$-labelled glycine. J. biol. Chem. 185, 657 .

Coleman, G. S. (1956). The dissimilation of amino acids by Rhodospirillum rubrum. J.gen. Microbiol. 15, 248.

Coleman, G. S. (1958). Maintenance of oligotrich protozoa from the sheep rumen in vitro. Nature, Lond. 182, 1104.

Coleman, G. S. $(1960 a)$. The eultivation of sheep rumen oligotrich protozoa in vitro. J. gen. Microbiol. 22, 555.

Coleman, G. S. $(1960 \mathrm{~b})$. Effect of penicillin on the maintenance of rumen oligotrich protozoa. Nature, Lond. 187, 518.

Coleman, G. S. (1962). The preparation and survival of bacteria-free suspensions of Entodinium caudatum. J. gen. Microbiol. 28, 271.

Dewey, V. C. \& Kidder, G. W. (1955). Threonine aldolase in Tetrahymena. Résumés communs. $3^{e}$ Congr. int. Biochem. Brussels, p. 92.

ElsDen, S. R. \& LewIS, D. (1953). The production of fatty acids by a Gram-negative coccus. Biochem. J. 55, 183.

Guillaume, J. \& Osteux, R. (1955). Détermination des acides aliphatiques volatils de $\mathrm{C}_{1}$ à $\mathrm{C}_{6}$ dans les liquids biologiques par chromatographie sur papier. C.R. Acad. Sci., Paris, 241, 501.

Gutierrez, J. \& Davis, R. E. (1962). Culture and metabolism of the rumen ciliate Epidinium ecaudatum (Crawley). Appl. Microbiol. 10, 305.

Hardy, T. L., Holland, D. O. \& Nayler, J. H. C. (1955). One-phase solvent mixtures for separation of amino acids. Analyt. Chem. 27, 971.

Horrocks, R. H. \& Manning, G. B. (1949). Partition chromatography on paper. Identification of reducing substances in urine. Lancet, $\mathrm{i}, 1042$.

HugGetT, A. St G. \& Nixon, D. A. (1957). Use of glucose oxidase, peroxidase and $o$-dianisidine in determination of blood and urinary glucose. Lancet, ii, 368.

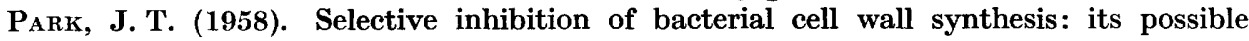
application in chemotherapy. In Strategy of Chemotherapy. Symp. Soc. gen. Microbiol. $8,49$.

Potter, V. R. \& Elvehuem, C. A. (1936). A modified method for the study of tissue oxidations. J. biol. Chem. 114, 495.

Roberts, R. B., Abelson, P. H., Cowie, D. B., Bolton, E. T. \& Britten, R. J. (1955). Studies on Biosynthesis in Escherichia coli. Publ. Carneg. Inst. no. 607.

Schneider, W. C. (1945). Phosphorous compounds in animal tissue. 1. Extraction and estimation of desoxypentose nucleic acid and of pentose nucleic acid. J. biol. Chem. 161, 293.

Williams, P. P., Davis, R. E., Doetsch, R. N. \& Gutierrez, J. (1961). Physiological studies of the rumen protozoon Ophyroscolex caudatus (Eberlein). Appl. Microbiol. 9, 405. 